\title{
Effect of Soft Tissue Thickness on the Morphology of Lip in Orthodontic Treatment
}

\author{
Efecto del Grosor del Tejido Blando en la Morfología del Labio en el Tratamiento de Ortodoncia
}

\author{
Yu-Xin Guan'; Li Xin²; Peng-Fei Tian; Hee-Moon Kyung³; Tae-Geon Kwon ${ }^{3}$; Li Bing ${ }^{1}$ \& Xiu-Ping Wu
}

GUAN, Y. X; XIN, L.; TIAN, P. F.; KYUNG, H. M.; KWON, T. G.; BING, L. \& WU, X. P. Effect of soft tissue thickness on the morphology of lip in orthodontic treatment. Int. J. Morphol., 37(4) :1245-1251, 2019.

SUMMARY: The aim of this study was to evaluate the effect of soft tissue thickness of upper lip on lip retraction in orthodonticaltreated females and identify the ratio of maxillary incisor retraction to upper lip retraction. Pre- and post-treatment lateral cephalograms of 100 adults were examined to measure the lip thickness in upper lip and establish the classification standard. All subjects were treated with 4 first premolar extractions followed by upper central incisors retraction. Pre- and post-treatment lateral cephalograms of 19 patients were reviewed to determine the changes of the upper lip and incisor positions through landmarks displacement.An independent-samples t test and one-way analysis of variance were performed. The correlations between maxillary incisor retraction and upper lip retraction were explored by the Pearson correlation method. P-values $<0.05$ were considered statistically significant. The lip thickness of adult male patients was greater than that of adult female patients. The average ratio of maxillary incisor retraction to upper lip repositioning was 1.6:1,1.9:1 and 2.2:1 in the thin lips group, normal lips group and thick lips group, respectively. Gender differences exist in the thickness of upper lip. Horizontal changes of the maxillary incisor showed a significant correlation to horizontal changes of the upper lip $(\mathrm{P}<0.001)$. There were negative correlations between the thickness of upper lip and the ratio between change in maxillary incisor protrusion and change in upper lip protrusion. profile.

KEY WORDS: Morphological characteristics; Malocclusion; Incisor retraction; Cephalometric measurements; Soft tissue

\section{INTRODUCTION}

For non-professionals, facial aesthetics place more emphasis on the aesthetic degree of facial soft issue. Therefore, patients who seek orthodontic treatment show concern to improve their appearance (Kuhn et al., 2016). The aesthetic standard of facial profile is affected by various factors such as race, ethnicity, gender, age, society and psychology, among which the lip shape is one of the most important factors affecting the aesthetic profile (Solem et al., 2013; Alkadhi et al., 2019). It is often involved the control of the incisor position to achieve the change of lip morphology in orthodontic treatment. In the case of bimaxillary protrusion, incisor retraction plays an important role in orthodontic treatment, predicting lip soft tissue changes that occur following premolar extractions to some extent (Solem et al.). However, it is a debatable issue whether or not there is an exact relationship in upper lip response to the saggital change of incisor position (Leonardi et al., 2010; Konstantonis, 2012; Alkadhi et al.).
The lip thickness has been also traditionally given little attention. Therefore, the primary aim of this study was undertaken to explore the response of lip position to incisor position and the association between upper lip thickness and upper lip repositioning upon maxillary incisor retraction in patients with bimaxillary dentoalveolar protrusion who had nearly completed active growth and were treated by extractions of four premolars, aiming to provide a reference for further clinical treatment.

\section{MATERIAL AND METHOD}

Establishment of lip thickness classification standard for Han population in Shanxi Province. The study population consisted of 100 adults (50 male, 50 female; $26.38 \pm 6.33$ years).

\footnotetext{
${ }^{1}$ Department of Orthodontics, School of Dentistry, Shanxi Medical University, Taiyuan, China.

${ }^{2}$ Department of Stomatology, Dalian Children's Hospital Affiliated to Dalian Medical University, Dalian, China.

${ }^{3}$ Department of Orthodontics, School of Dentistry, Kyungpook National University, Daegu, Korea.

FUNDING: Major international science and technology cooperation projects of Shanxi Province No. 201803D421062, No. 2015081030

Major science and technology projects of Shanxi Province No. 201803 D31065
} 
Inclusion criteria was Han people in Shanxi. Patients with previous history of trauma, maxillofacial surgery or orthodontics were excluded. Pre- and post-treatment cephalograms were calibrated and digitally traced by one examiner using "Uceph"( Orthodontic Software, Sichuan, China). Secondary analyses were performed by dividing data into three groups based on pre- treatment upper lip thickness using the quartiles as cut- off points (Oliver, 1982).Each group was ranked according to the lip thickness. The samples less than $25 \%$ were in thin lips group, $25-75 \%$ were in normal lips group, and more than or equal to $75 \%$ were in thick lips group. The identified landmarks and measuring projects were displayed in Fig. 1 and described in Table I.

The effect of upper lip thickness on the amount of incisor retraction required to reduce lip procumbency. The sample consisted of 19 consecutive nongrowing Asian females (mean age, 25.4 \pm 5.89 years; range, 19-36 years) with a chief complaint of lip protrusion. All were treated with 4 first premolar extractions followed by anterior retraction in the orthodontic clinic at the University of Shanxi, China. The following inclusion criteria were applied:(1) bimaxillary dentoalveolar protrusion; (2) Class I and Class Division 1 molar relationships; (3) the availability of 2 lateral cephalograms of good quality depicting; (4) lips in a relaxed closed position. Patients with craniofacial syndromes, such as cleft lip and palate, facial asymmetry or congenitally missing teeth were excluded. According to the statistical results, 19 female patients were divided into thin lips group, normal lips group and thick lips group, and the ratio between maxillary incisor retraction and upper lip repositioning was calculated, respectively. For the cephalometric analysis, two reference

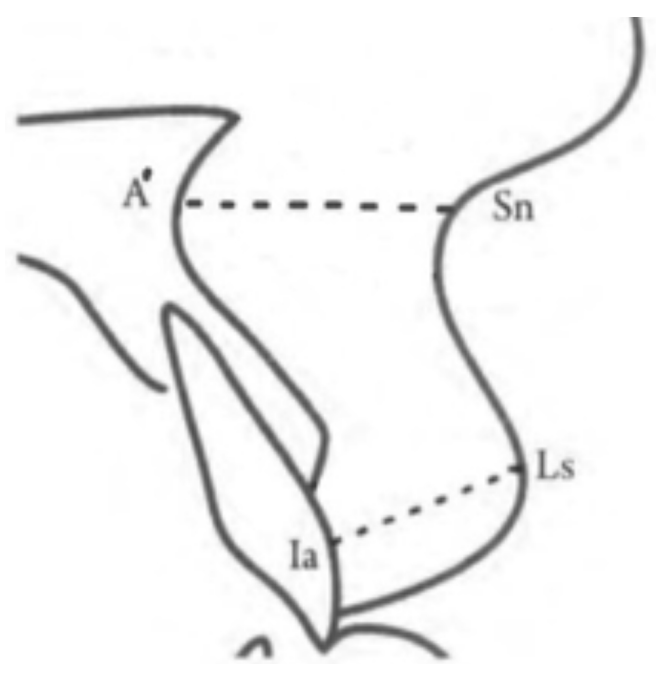

Fig. 1.Measuring of lip thickness. Sn.Subnasale; A'.Holdaway point; Ls. the vermillion margin of the upper lip; Ia. The most labial surface of the maxillary incisor. lines were constructed; a horizontal reference line $\left(\mathrm{SN}-7^{\circ}\right)(\mathrm{X}-$ axis) through Sella seven degrees inferior to the Sella-Nasion line, and a vertical reference line (Y-axis) through Sella perpendicular to $\mathrm{SN}-7^{\circ}$ (Hayashida et al., 2011). Upper lip protrusion and maxillary incisor position were measured in relationship to the vertical reference plane (Fig. 2, Table I).

Statistical Analyses. All statistical analyses were performed with SPSS version 24 (SPSS, IBM $\odot$, Armonk, NY, USA) to test the significance of the differences between the change values. Based on their skewness and kurtosis, the distributions were all normal. Independent-sample t-tests were used to evaluate the significance of the differences between males and females. Differences between the cephalometric variables before and after treatment were analyzed by using paired-t test. ANOVA was applied to compare the differences of upper lip thickness among the three groups. Post hoc tests were done using the LSD-t method and correlation analysis was conducted between the ratio of maxillary incisor retraction to upper lip retraction and upper lip thickness. Bivariate regressions were performed to determine the relationships between the upper lip thickness and the ratio of hard to soft tissue movement commonly used for predicting soft tissue changes. The linear regression model was used to investigate possible associations between different ranges of lip thickness and the average ratio of maxillary incisor to upper lip repositioning. P-values less than 0.05 were considered statistically significant.

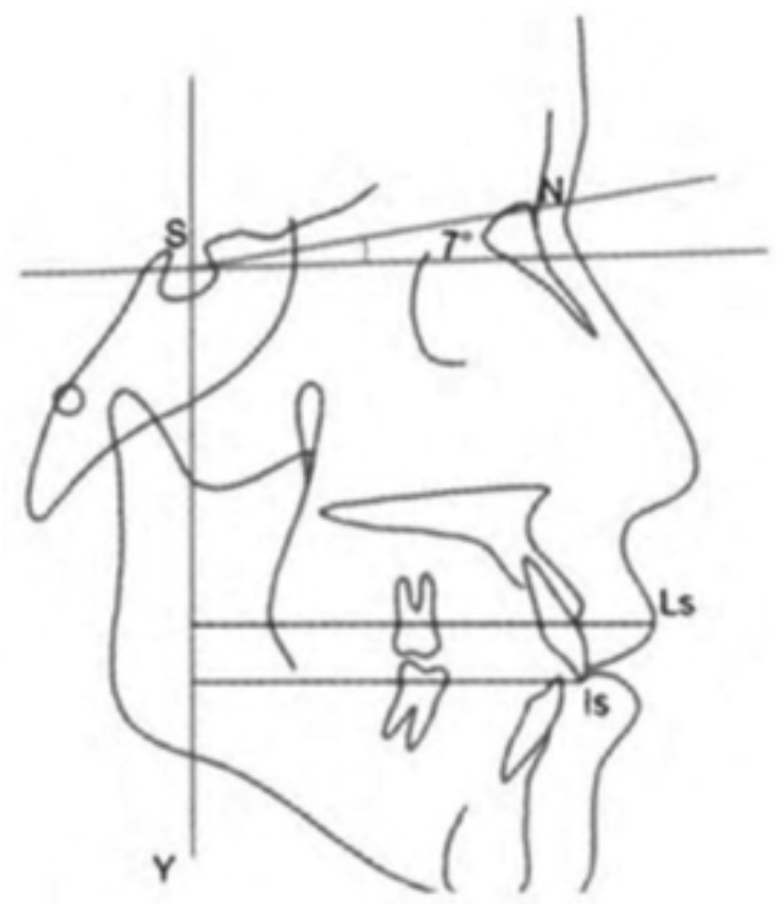

Fig. 2. Measuring of incisor and upper lip retraction. S; Sella; N: Nasion; Ls: Labrale superius; Is: Incisor superius. 
Table. I Cephalometric Analysis Measurements.

\begin{tabular}{lll}
\hline Abbre viation & Name & Definitions \\
\hline A'-Sn & Basic upper lip thickness & Linear distance from (A') to subnasale (Sn) \\
Ia-Ls & Vermillion upper lip thickness & $\begin{array}{l}\text { Linear distance from the most labial surface of the maxillary incisor } \\
\text { (Ia) to the vermillion border of the upper lip (Ls) }\end{array}$ \\
LT & Lip thickness & Average upper lip thickness at basic and vermillion upper lip \\
_Is-Y & The amount of the maxillary incisor & Linear distance from Is to SN-7 ${ }^{\circ}$ perpendicular \\
_Ls-Y & The amount of the upper lip & Linear distance from Ls to SN-7 $7^{\circ}$ perpendicular \\
\hline
\end{tabular}

\section{RESULTS}

Establishment of lip thickness standard for Han population in Shanxi Province. Means and standard deviations of males, females cephalometric values, and the observed changes between them were displayed in Table II. A statistically significant difference between the sexes was found. The upper lip thickness of the male was greater than that of the female $(\mathrm{P}<0.001)$. To further investigate this primary finding, we divided our sample in three groups, based on their lip thickness. For males, first group fell within the lower 25 percent $(<13.9 \mathrm{~mm} ; \mathrm{n}=14)$ and was considered to have thin lips, while third group fell within the upper 75 percent $(>15.9 \mathrm{~mm} ; \mathrm{n}=12)$ and was considered to have thick lips; the rest was the normal group (13.9-15. $\mathrm{mm} ; \mathrm{n}=24)$. For females, first group fell within the lower 25 percent $(<12.3 \mathrm{~mm} ; \mathrm{n}=15)$ and was considered to have thin lips, while third group fell within the upper 75

Table II Comparison of upper lip thickness between males and females $(\mathrm{n}=50)$.

\begin{tabular}{lccll}
\hline Measurement & Male $(\mathrm{n}=50)$ & Female $(\mathrm{n}=50)$ & $\mathrm{t}$ & $\mathrm{P}$ \\
\hline A'-Sn & $13.74 \pm 1.95$ & $11.45 \pm 2.19$ & 5.51 & $<0.001$ \\
Ia-Ls & $16.11 \pm 2.50$ & $14.75 \pm 2.20$ & 2.88 & $<0.005$ \\
LT & $14.92 \pm 1.68$ & $13.10 \pm 1.70$ & 5.40 & $<0.001$ \\
\hline
\end{tabular}

percent $(>14.2 \mathrm{~mm} ; \mathrm{n}=12)$ and was considered to have thick lips; the rest was the normal group(12.3-14.2 mm; $\mathrm{n}=23$ ). We applied ANOVA to investigate statistical significance for different lip thickness groups, as shown in Table III.

The ratio between maxillary incisor retraction and upper lip repositioning with different lip thickness. This study demonstrated that a significant retraction of the upper lip following premolar extractions in bi-protrusive patients occurred with treatment. In thin lips group, the position of the maxillary incisor relative to $\mathrm{SN}-7^{\circ}$ perpendicular was $82.20 \mathrm{~mm}(\mathrm{SD}, 10.30)$ at $\mathrm{T} 1$. At T2, its position was 75.20 $\mathrm{mm}$ (SD, 12.38), a change of $-7.00 \mathrm{~mm}$ (SD,3.06). The position of the upper lip in relationship to the vertical reference plane was $95.10 \mathrm{~mm}(\mathrm{SD}, 10.53)$ at $\mathrm{T} 1$. At $\mathrm{T} 2$, its position was $90.30 \mathrm{~mm}(\mathrm{SD}, 13.47)$, a change of $-4.80 \mathrm{~mm}(\mathrm{SD}, 3.13)$. The results of normal lips group and thick lips group were similar to those of thin lips group (Tables IV, V and VI). Furthermore, thick lips would experience less lip retraction. A significant correlation was found between changes in maxillary incisor position following premolars extraction and changes in upper lip position ( $\mathrm{r}=0.959$, $\mathrm{P}<0.001$ ) (Fig. 3). The bivariate association between

Table III Analysis of variance for different lip thickness groups.

\begin{tabular}{|c|c|c|c|c|c|c|c|c|}
\hline \multirow[t]{2}{*}{ Group } & $\begin{array}{l}\text { Thin } \\
\text { lips/mm(1) }\end{array}$ & $\begin{array}{l}\text { Normal } \\
\text { lips/mm(2) }\end{array}$ & $\begin{array}{l}\text { Thick } \\
\text { lips/mm(3) }\end{array}$ & $\mathrm{F}$ & $\mathrm{P}$ & (1)and (3) & $\begin{array}{l}\text { P(LSD-t) } \\
\text { (2) and (3) }\end{array}$ & (1) and (3) \\
\hline & Mean SD & Mean SD & Mean SD & & & & & \\
\hline Male & 12.880 .65 & 15.000 .55 & 17.130 .87 & 132.43 & $<0.001$ & $<0.001$ & $<0.001$ & $<0.001$ \\
\hline Female & 11.240 .88 & 13.150 .61 & 15.340 .93 & 92.90 & $<0.001$ & $<0.001$ & $<0.001$ & $<0.001$ \\
\hline
\end{tabular}

Table. IV Table IV Descriptive statistics of pre- (T1) and post-treatment (T2) measurements in the thin lips group.

\begin{tabular}{|c|c|c|c|c|c|c|c|}
\hline & $\mathrm{TI}$ & & $\mathrm{T} 2$ & & T2-T1 & & \\
\hline V ariable $(\mathrm{mm})$ & Mean & SD & Mean & SD & Mean & SD & $P$ value \\
\hline Lip thickness & 11.39 & 0.82 & 12.79 & 0.97 & 1.40 & 1.73 & $<0.001$ \\
\hline Is to $\mathrm{SN}-7^{\circ}$ perpendicular & 82.20 & 10.30 & 75.20 & 12.38 & -7.00 & 3.06 & $<0.001$ \\
\hline Ls to $\mathrm{SN}-7^{\circ}$ perpendicular & 95.10 & 10.53 & 90.30 & 13.47 & -4.80 & 3.13 & $<0.001$ \\
\hline
\end{tabular}


GUAN, Y. X; XIN, L.; TIAN, P. F.; KYUNG, H. M.; KWON, T. G.; BING, L. \& WU, X. P. Effect of soft tissue thickness on the morphology of lip in orthodontic treatment. Int. J. Morphol., 37(4):1245-1251, 2019

Table .V Table V Descriptive statistics of pre- (T1) and post-treatment (T2) measurements in the normal lips group

\begin{tabular}{llllllll}
\hline \multirow{2}{*}{ Variable $(\mathrm{mm})$} & TI & \multicolumn{5}{c}{ T2 } & \multicolumn{3}{c}{ T2-T1 } & \multirow{2}{*}{ P value } \\
\cline { 2 - 6 } & Mean & SD & Mean & SD & Mean & SD & \\
\hline Lip thickness & 13.26 & 0.51 & 13.95 & 0.70 & 0.69 & 0.38 & $<0.001$ \\
Is to SN-7 ${ }^{\circ}$ perpendicular & 75.36 & 14.68 & 68.71 & 17.66 & -6.64 & 4.47 & $<0.001$ \\
Ls to SN-7 $^{\circ}$ perpendicular & 87.71 & 16.25 & 84.29 & 18.11 & -3.43 & 3.81 & $<0.001$ \\
\hline
\end{tabular}

Table. VI Table VI Descriptive statistics of pre- (T1) and post-treatment (T2) measurements in the thick lips group.

\begin{tabular}{|c|c|c|c|c|c|c|c|}
\hline \multirow[b]{2}{*}{ Variable(mm) } & \multicolumn{2}{|l|}{ TI } & \multicolumn{2}{|l|}{$\mathrm{T} 2$} & \multicolumn{2}{|c|}{ T2-T1 } & \multirow[b]{2}{*}{$P$ value } \\
\hline & Mean & SD & Mean & SD & Mean & SD & \\
\hline Lip thickness & 15.36 & 0.88 & 15.65 & 0.86 & 0.25 & 0.08 & $<0.001$ \\
\hline Is to $\mathrm{SN}-7^{\circ}$ perpendicular & 95.94 & 8.08 & 92.64 & 8.61 & -3.30 & 2.96 & $<0.001$ \\
\hline Ls to $\mathrm{SN}-7^{\circ}$ perpendicular & 108.14 & 8.31 & 106.64 & 8.56 & -1.50 & 1.41 & $<0.001$ \\
\hline
\end{tabular}

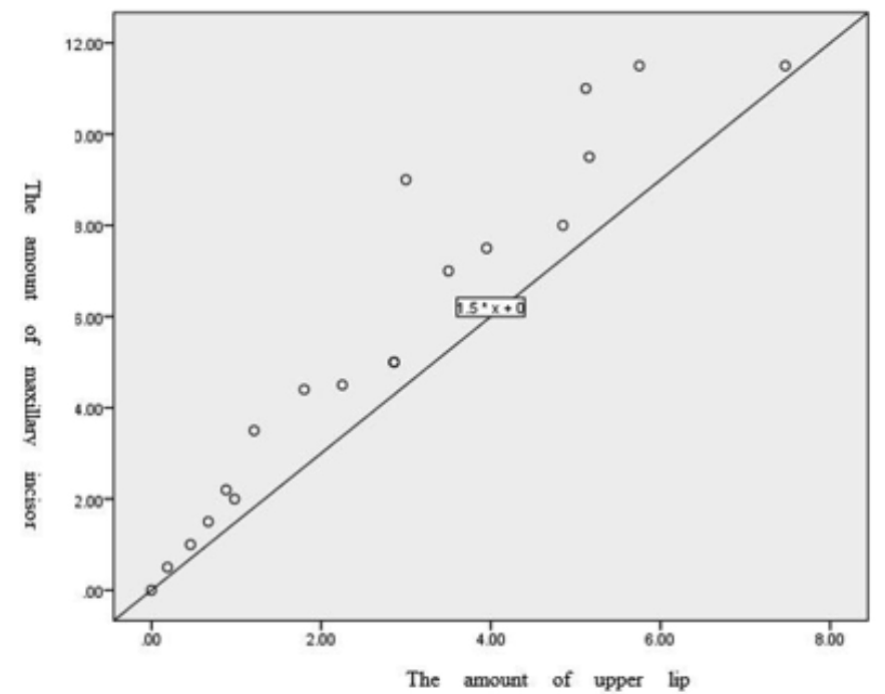

Fig. 3. The correlation between maxillary incisor retraction and lip retraction.

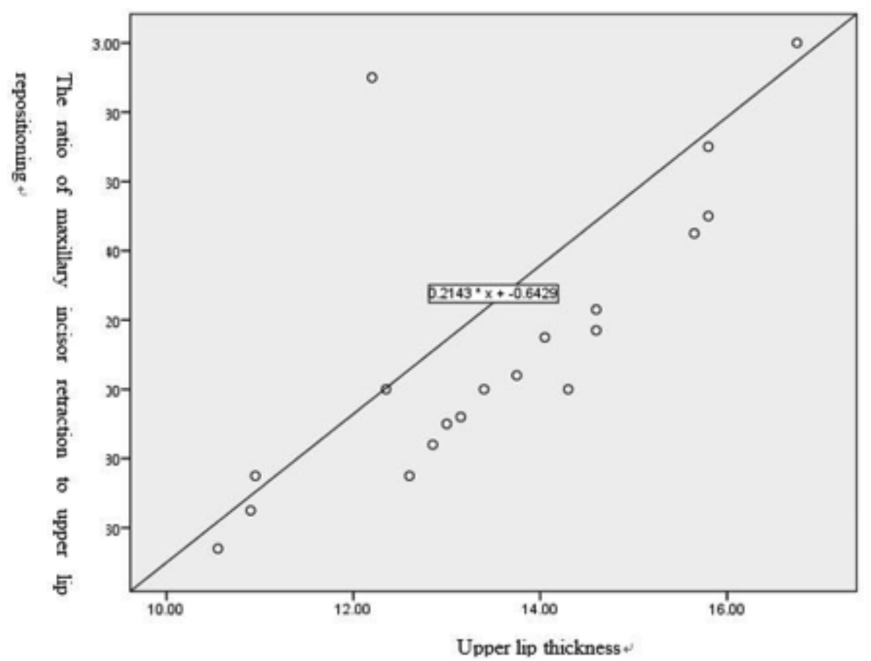

Fig. 4. The relationship between upper lip thickness and the ratio of maxillary incisor retraction to upper lip retraction. upper lip and the underlying hard tissue retraction was moderately strong ( $\mathrm{r}=0.735, \mathrm{P}<0.001)$ (Fig. 4). The difference of upper lip thickness had a negative correlation with the retraction of upper lip. When we divided our pretreatment sample (females) into 3 groupsthin $(n=5)$, normal $(n=7)$, and thick $(n=7)$, there were

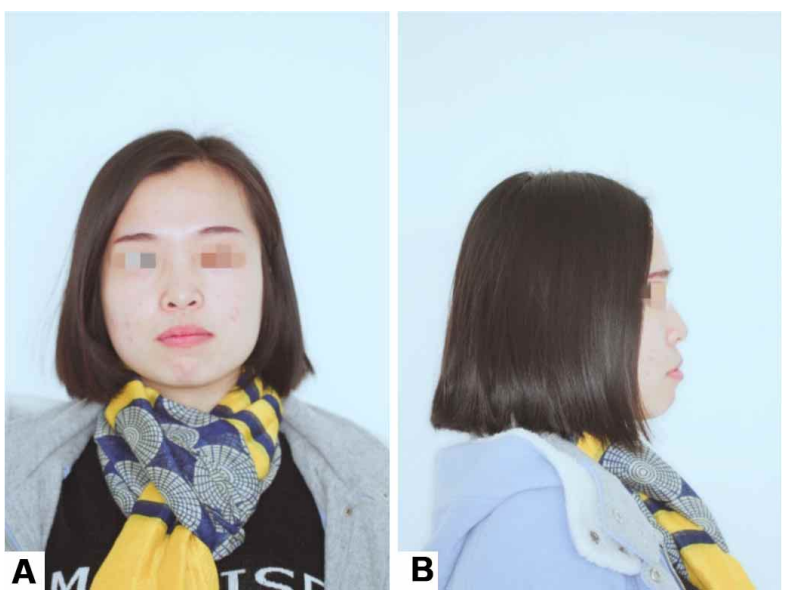

Fig. 5.Pre-treatment frontal (A) and profile (B) photographs.
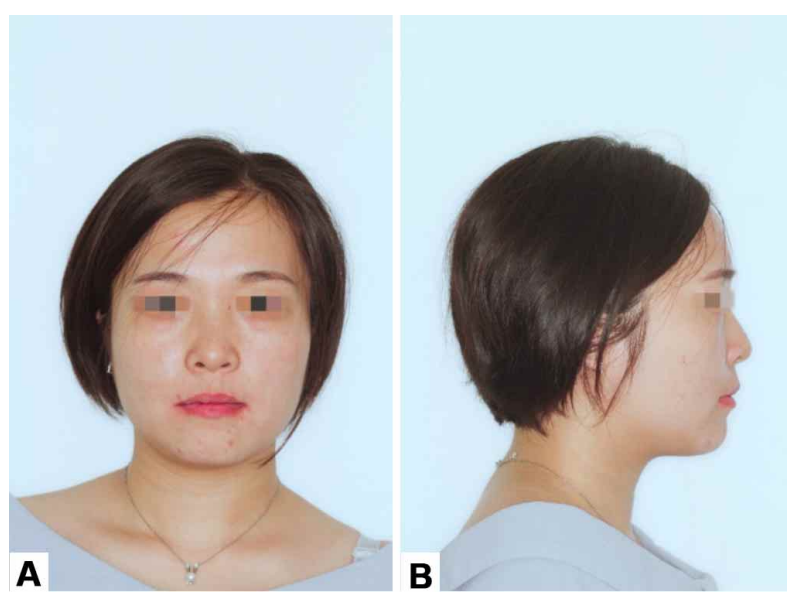

Fig. 6. Post-treatment frontal (A) and profile (B) photographs. 
significant differences in the change of the measurements $(\mathrm{P}<0.001)$. The ratio between retraction of the upper incisal edge and labrale superioris was 1.6:1, 1.9:1 and 2.2:1 in thin lips group, normal lips group and thick lips group, respectively.

Typical cases. The facial profile of this patient was improved primarily by the retraction and retroclination of maxillary incisors to decrease upper lip procumbency and convexity (Figs. 5 and 6). The pre- and post-treatment lateral cephalometric analysis was compared, as shown in Fig. 7 and Table VII.
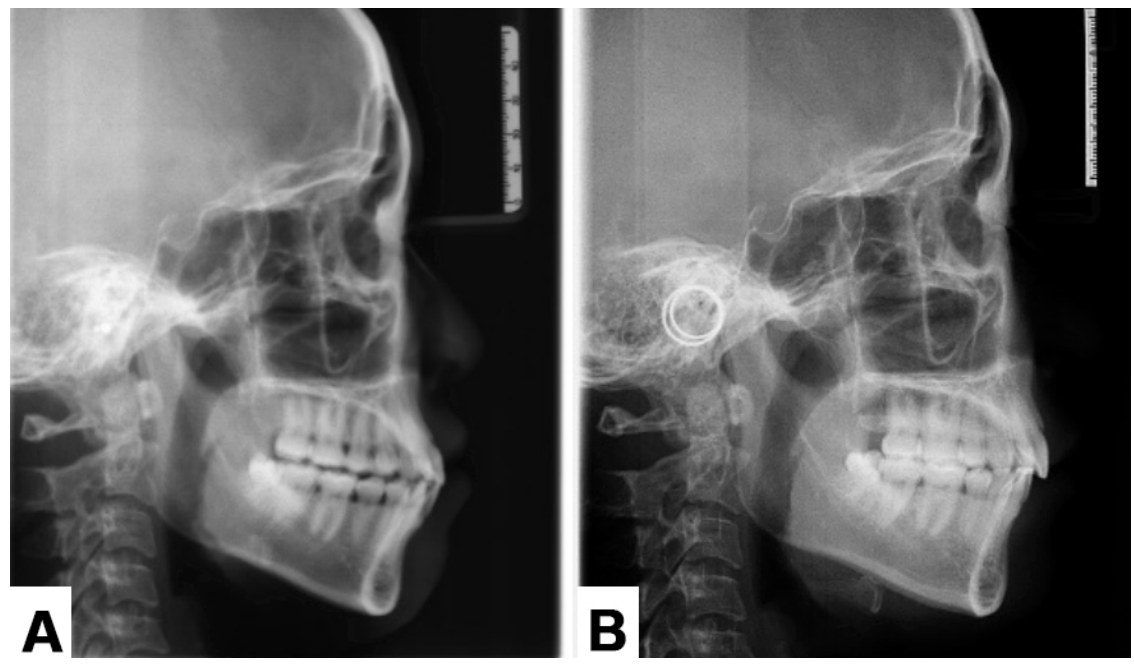

Fig.7. Pre- (A) and post-(B) treatment lateral cephalograms.

Table VII. Cephalometric Measurements at Pretreatment and Posttreatment

\begin{tabular}{llllll}
\hline $\begin{array}{l}\text { Measurement } \\
\text { Skeletal }\end{array}$ & \multicolumn{2}{l}{ Chinese Female Norm } & Pretreatment & Posttreatment & Difference \\
\hline SNA $\left({ }^{\circ}\right)$ & 81.7 & 2.5 & 85.0 & 82.6 & -2.4 \\
SNB $\left({ }^{\circ}\right)$ & 78.97 & 2.2 & 83.4 & 80.5 & -2.9 \\
ANB $\left(^{\circ}\right)$ & 2.8 & 1.2 & 1.6 & 2.1 & 0.5 \\
SN-MP( $\left(^{\circ}\right)$ & 32.9 & 4.2 & 31.5 & 33.7 & 2.2 \\
FMA $\left(^{\circ}\right)$ & 31.3 & 5.0 & 30.8 & 29.1 & -1.7 \\
Dentoalveolar & & & & & \\
U1-SN $\left(^{\circ}\right)$ & 74.9 & 6.2 & 112.2 & 102.2 & -10.0 \\
U1-NA(mm) & 5.6 & 3.6 & 6.7 & 5.8 & -0.9 \\
U1-NA $\left({ }^{\circ}\right)$ & 23.3 & 6.2 & 27.2 & 19.6 & -7.6 \\
L1-MP( $\left(^{\circ}\right)$ & 93.9 & 6.2 & 100.8 & 92.0 & -8.8 \\
L1-NB $(m m)$ & 5.8 & 2.3 & 6.7 & 4.20 & -2.5 \\
L1-NB $\left({ }^{\circ}\right)$ & 27.4 & 4.7 & 35.7 & 26.2 & -9.5 \\
U1-L1 $\left({ }^{\circ}\right)$ & 123.2 & 6.2 & 115.5 & 132.1 & 16.6 \\
U1-APO(mm) & 6.7 & 2.0 & 12.6 & 9.0 & -3.6 \\
L1-APO(mm) & 3.3 & 1.8 & 10.8 & 4.8 & -6.0 \\
Soft tissue & & & & & \\
UL-E $(m m)$ & -0.5 & 1.9 & 0.5 & 1.7 & 1.2 \\
LL-E(mm) & 1.3 & 1.9 & 4.1 & 2.9 & -1.2 \\
\hline
\end{tabular}


changes. It should be clear that this assumption can be true only when described changes are observed during the post treatment period until the completion of growth. The intertegmental profile can be accomplished with consideration of patients who had nearly completed active growth, so as to reduce growth effects (Kuhn et al.). In addition to age effects, sex differences in growth need to be taken into consideration, because women have less growth potential and reach maturity years before men. There is a difference between sexes regarding the lipincisor relation at this age. Males presented thickening of soft tissue and week correlation between the movement of incisor and soft tissue both cervical and incisal point. In female subjects, there was a strong correlation between the retraction movement and soft tissue (Paranhos et al., 2013). Considering the above, there are, to my mind, plenty of contributing causes, among which the following one that is the object of this experiment, lip thickness, is particularly worth. Thicker lips appear to respond less to incisor movement and provide better supports to lip morphology (Alkadhi et al.). It also needs to be noted that extraction treatments tends to flatten the profile, whereas nonextraction treatment has a tendency to make it more protrusive. The study by Bills et. al., (2005) al showed that premolar extractions can be successful in reducing lip procumbency in patients with bimaxillary protrusion. On average, the upper lip retracted by $3 \mathrm{~mm}$ and the lower lip showed a $2.4 \mathrm{~mm}$ retraction (Petrén et al., 2003; Bills et al.). As has been shown (Konstantonis). The extraction group terminated treatment with more retracted lips, a more obtuse nasolabial angle, and a thicker upper lip. Whereas the nonextraction group showed significant upper lip retraction but lower lip protraction. Last but not least, one should bear in mind that individual variation in soft tissue response is great. In short, We were obliged to carefully design this study in the selection of included samples, so as to reduce many of the variables that could adversely affect the results.

To ideally rebuild lip shape, the exact prediction of retraction extent of incisor is a wide-ranging discussion. This study, obviously, would be of help for the clinicians who predict soft tissue changes attributed to incisor retraction. This, in turn, would assist the clinicians in making extraction decisions and determining the amount of incisor retraction required to reduce lip procumbency and convexity.

GUAN, Y. X; XIN, L.; TIAN, P. F.; KYUNG, H. M.; KWON, T. G.; BING, L. \& WU, X. P. Efecto del grosor del tejido blando en la morfología del labio en el tratamiento de ortodoncia. Int. J. Morphol., 37 (4):1245-1251, 2019.
RESUMEN: El objetivo de este estudio fue evaluar el efecto del grosor de los tejidos blandos del labio superior, sobre la retracción del labio en mujeres tratadas con ortodoncia e identificar la proporción de retracción del diente incisivo maxilar con respecto a la retracción del labio superior. Se examinaron cefalogramas laterales, previos y posteriores al tratamiento de 100 adultos, para medir el grosor del labio superior y establecer un estándar de clasificación. Todos los sujetos fueron tratados con 4 extracciones de los primeros premolares seguidas de retracción de los incisivos centrales superiores. Se revisaron los cefalogramas laterales, previos y posteriores al tratamiento de 19 pacientes, para determinar los cambios del labio superior y las posiciones de los incisivos a través del desplazamiento de los puntos de referencia. Se realizó una prueba t de muestras independientes y un análisis de varianza de una vía. Las correlaciones entre la retracción del incisivo maxilar y la retracción del labio superior se exploraron mediante el método de correlación de Pearson. Los valores de $\mathrm{p}<0,05$ fueron considerados estadísticamente significativos. El grosor de los labios de los pacientes adultos masculinos fue mayor que el de las pacientes adultas. La relación promedio de la retracción del incisivo maxilar al reposicionamiento del labio superior fue de 1,6:1,1; 9:1 y 2,2:1 en el grupo de labios delgados, grupo de labios normales y grupo de labios gruesos, respectivamente. Existen diferencias de sexo en el grosor del labio superior. Los cambios horizontales del incisivo maxilar mostraron una correlación significativa con los cambios horizontales del labio superior $(\mathrm{P}<0,001)$. Hubo correlaciones negativas entre el grosor del labio superior y la relación entre el cambio en la protuberancia del incisivo maxilar y el cambio en la protrusión del labio superior.

PALABRAS CLAVE: Características morfológicas; Maloclusión; Retracción del incisivo; Medidas cefalométricas; Perfil de tejidos blandos.

\section{REFERENCES}

Alkadhi, R. M.; Finkelman, M. D.; Trotman, C. A. \& Kanavakis, G. The role of lip thickness in upper lip response to sagittal change of incisor position. Orthod. Craniofac. Res., 22(1):53-7, 2019.

Arumugam, E.; Duraisamy, S.; Ravi, K. \& Krishnaraj, R. Prediction of soft tissue profile changes following orthodontic retraction of incisors in South Indian females. SRM J. Res. Dent. Sci., 3(1):10-4, 2012.

Bills, D. A.; Handelman, C. S. \& BeGole, E. A. Bimaxillary dentoalveolar protrusion: traits and orthodontic correction. Angle Orthod., 75(2):3339, 2005.

Brock, R. A. 2nd; Taylor, R. W.; Buschang, P. H. \& Behrents, R. G. Ethnic differences in upper lip response to incisor retraction. Am. J. Orthod. Dentofacial Orthop., 127(6):683-91, 2005

Hayashida, H.; Ioi, H.; Nakata, S.; Takahashi, I. \& Counts, A. L. Effects of retraction of anterior teeth and initial soft tissue variables on lip changes in Japanese adults. Eur. J. Orthod., 33(4):419-26, 2011.

Kirschneck, C.; Proff, P.; Reicheneder, C. \& Lippold, C. Short-term effects of systematic premolar extraction on lip profile, vertical dimension and cephalometric parameters in marginline patients for extraction therapy-a retrospective cohort study. Clin. Oral Investig., 20(4):865-74, 2016.

Konstantonis, D. The impact of extraction vs nonextraction treatment on soft tissue changes in Class I marginline malocclusions. Angle Orthod., 82(2):209-17, 2012 
Kuhn, M.; Markic, G.; Doulis, I.; Göllner, P.; Patcas, R. \& Hänggi, M. P. Effect of different incisor movements on the soft tissue profile measured in reference to a rough-surfaced palatal implant. Am. J. Orthod. Dentofacial Orthop., 149(3):349-57, 2016.

Kusnoto, J. \& Kusnoto, H. The effect of anterior tooth retraction on lip position of orthodontically treated adult Indonesians. Am. J. Orthod. Dentofacial Orthop., 120(3):304-7, 2001.

Leonardi, R.; Annunziata, A.; Licciardello, V. \& Barbato, E. Soft tissue changes following the extraction of premolars in nongrowing patients with bimaxillary protrusion. A systematic review. Angle Orthod., 80(1):211-6, 2010.

Oliver, B. M. The influence of lip thickness and strain on upper lip response to incisor retraction. Am. J. Orthod., 82(2):141-9, 1982.

Paranhos, L. R.; Benedicto, E. de N. \& Ramos, A. L. Changes of the upper lip in orthodontic and orthopedic treatment of angle's class II malocclusion. Indian J. Dent. Res., 24(3):351-5, 2013.

Petrén, S.; Bondemark, L. \& Söderfeldt, B. A systematic review concerning early orthodontic treatment of unilateral posterior crossbite. Angle Orthod., 73(1):588-96, 2003.

Ramos, A. L.; Sakima, M. T.; Pinto Ados, S. \& Bowman, S. J. Upper lip changes correlated to maxillary incisor retraction--a metallic implant study. Angle Orthod., 75(2):499-505, 2005.

Sodagar, A.; Borujeni, D. G. \& Amini, G. Prediction of soft tissue profile changes following orthodontic retraction of incisors in Iranian girls. World J. Orthod., 11(3):262-8, 2010.

Solem, R. C.; Marasco, R.; Guiterrez-Pulido, L.; Nielsen, I.; Kim, S. H. \& Nelson, G. Three-dimensional soft-tissue and hard-tissue changes in the treatment of bimaxillary protrusion. Am. J. Orthod. Dentofacial Orthop., 144(2):218-28, 2013.

\author{
Corresponding author: \\ Li Bing \& Xiu-Ping Wu \\ Stomatology Hospital \\ Shanxi Medical University \\ 63 Xinjian Road, Taiyuan 030001 \\ CHINA
}

Email: libing-1975@163.com

Received: 21-03-2019

Accepted: 21-06-2019 